\title{
Influence of Socially Disadvantaged Environment on Aggressiveness of Pupils at Primary Schools
}

\author{
Dáša Porubčanová - Lenka Pasternáková*
}

\author{
Received: October 13, 2017; received in revised form: March 19, 2018; \\ accepted: March 21, 2018
}

\begin{abstract}
:
Introduction: The study deals with occurrence of aggressiveness of pupils from socially disadvantaged environment. It describes the socially disadvantaged environment and the level of aggression of pupils from such environments. The text describes the most important results of the research.

Methods: Within the research, a survey was carried out, monitoring the level of aggression of the majority pupils compared to the pupils from socially disadvantaged environment. The survey was carried out personally based on a monitoring scheme of aggression of the pupils from socially disadvantaged environment. The research has been made by direct observation within 60 teaching hours at the level of 1 st and 4 th grade.

Results: The findings, which we have acquired through observation, showed that the age and maturity of younger pupils' organisms adapts to the model of social environment. Pupils from less stimulating social environments may become the victims of aggressive attacks in various forms more frequently. Types, forms and manifestations of aggression, equally subject to influence of the environment, in a school environment at the level of 10 -year-old students are perceived as some form of entertainment. They join the attack on the victim for acceptance or they have the same preferences as the group. It often happens without consequences or attempts to eliminate these signs, because the seriousness of the attack is not ascribed.

Discussion: We were interested in the differences of aggression level of the majority pupils compared to the pupils from socially disadvantaged environment in the first and the fourth year of a primary school.

Limitations: The results apply only to students in the first level by using of the observation method.

Conclusions: As substantial and significant for pedagogic experience, we consider implementing the research findings as well on the higher level of pupils' education and to define further correlations between aggressive behaviour and socially disadvantaged environment.
\end{abstract}

Key words: socially disadvantaged environment, aggressiveness, prevention.

\footnotetext{
* Dáša Porubčanová, DTI University, Department of School Didactics, Dubnica nad Váhom, Slovakia; porubcanova@dti.sk

Lenka Pasternáková, Prešov University in Prešov, Faculty of Humanities and Natural Sciences, Prešov, Slovakia; lenka.pasternakova@unipo.sk
} 


\section{Acta Educationis Generalis \\ volume 8, 2018, issue 1}

\section{Introduction}

The most straightforward definition of aggressiveness defines the term as intentional hurting, causing negative consequences. In particular - aggressiveness is a form of behaviour. Aggression is neither thinking about doing something wrong with someone, nor planning and imagining how to hurt or harm someone.

According to Výrost and Slaměník (2008), aggressiveness is a form of behaviour that either causes hurt and harm or it leads to such hurt. It is not important what the real consequences of aggressive behaviour are. It can be injuries and physical pain. Aggression can also take the form of damage to someone else's property or psychological injury to another person. It can be anything that causes disgust and psychological discomfort. According to experts, aggression is a manifestation of aggressiveness and it is defined as offensive or hostile behaviour, hostility to a particular object, deliberate attack on an obstacle, a person, and an object standing in the way to meet the aggressor's needs.

\section{Theoretical framework}

Határ (2004) defines aggression as hostility, violence and explosiveness in behaving to a particular object, attacking an obstacle on the way to satisfying one's needs.

We agree with Dupkalová and Krajčová (2015), that a person has genetic predispositions to aggressive behaviour; however, such dispositions do not depend on genes only, as they develop by learning and the influence of the environment. Society's tolerance for aggression and aggressive behaviour has varied over time and it is constantly changing, and the social climate can also reduce aggression to something banal and to indirectly support it.

A large number of psychologists dealing with the issues of aggression (Kyriacou, 2001, Rozvadský Gugová \& Eisemann, 2016) agree that aggression, similar to the majority of human behaviour is learned, based on experience, and mediated based on the surrounding environment. A person realizes easily that aggressive behaviour surely pays. It allows the aggressors to seize an object that they desire, to get a service they need, to avoid duties, etc. If a child is successful with such aggressive behaviour, then they create a lot of aggressive models in their behaviour. They deduce principles, attitudes, values that affect people in their surroundings. The child expresses the thoughts, feelings and beliefs in violation of the rights of others. Its goal is to win over any other people and to conquer them (Verbovská, 2001).

Experts classify different types of aggression. The most common classification defines two types of aggression (Zahatňanská, 2015):

1. Verbal aggression - realized as different verbal assaults (such as swearing, shouting or tormenting);

2. Physical aggression - includes a large number of a direct contact of an aggressor and a victim (such as fighting, hurting or torture).

By Čermák (1999), both types of aggression are either direct or indirect. Spurný (1996) further classifies them as:

1. Open, direct aggression - aggression towards a person who the aggressor dislikes;

2. Indirect aggression - aggression towards the values that are important for the victim;

3. Displaced aggression - if a substitute target of aggression is used; 


\section{Acta Educationis Generalis \\ volume 8,2018 , issue 1}

4. Imitative aggression - imitating aggressive behaviour modelled by another person, such as bullying of new recruits in the army;

5. Introverted aggression - meaning self-aggression, with its extreme form, a suicide.

Regarding its length, Erb (2000) defines:

1. Short-term aggression - usually primitive, spontaneous, with a violent disgust of affection; its participants lose the ability to assess the scope, objective and motivation;

2. Long term aggression - usually considered well, repeated, taking a longer period of time.

Határ (2004) defines aggression by its nature as:

1. Benign aggression (adaptive aggression) - is not spontaneous; is a reaction to a certain stimulus and is of a protective nature; it is a phylo-genetically programmed adaptive response to endangering the animal's vital interests.

2. Malign aggression - manifested by destructiveness and cruelty distorting social structures; appears only in humans and is neither phylo-genetically programmed nor instinctive.

3. Pseudo-aggression - its primary purpose is not to cause any damage, but it can cause it.

4. Unintentional aggression - accidental, the purpose of which was not to harm.

5. Protective aggression - as a reaction to physical and mental threats.

6. Conformity aggression - natural to animals and humans, and its aim is to protect life.

Aggressive behaviour reacts to problems by aggression, meaning such behaviour intentionally hurting, and limiting other people, keeping them from doing different activities.

Aggression and aggressive behaviour of children may take different forms. Winkel, a German educationalist, defined five types of aggression of children and teenagers:

1. Aggression as a game - its aim is either to try the possibilities or to enjoy the victory. However, there is a danger that children's play or entertainment can go through to a serious form of aggression.

2. Aggression as a defensive mechanism - defending the victim against the attacker. The attracter may get hurt seriously.

3. Aggression as the reaction of a frustrated individual - the child seeks compensation for their loss in weaker individuals.

4. Aggression as curiosity - a child wants to know where the limits are, what they can afford and what not. This form of aggression can result in an egoistic promotion of the child's own power.

5. Aggression as inappropriate desire for love - the child seeks to get the attention of the environment, especially by negative behaviour. May be dangerous due to masochistic satisfaction of the child's own needs, while the aggressor does not realize their actions (Zahatňanská, 2015).

By Kolár (2001), all the aggressors share a common striking, though not always conscious, desire for power and cruelty. It is considered to be the driving force of their 


\section{Acta Educationis Generalis \\ volume 8, 2018, issue 1}

aggression. Common motives of aggressive behaviour include: attracting attention - an aggressor is trying to become the centre of attention, capturing the surroundings, engage the attention of the peers; killing boredom - it is typical of the aggressor who disconnected, to whom aggression provides a stimulus strong enough to feel some satisfaction; Mengele's motive - an aggressor feels like a scientist, doing research on what a person is able to bear; jealousy - an aggressor revenges a victim for having a good school performance and being popular with teachers; prevention - is typical for aggressors with previous experience as a victim, they either join the group of aggressors or become aggressors themselves not to become victims again; effort to do something great - for some aggressors, this is the only way to prove that they are capable of performing and the only reason for the others to remember.

The aggressors may initiate aggression either occasionally or chronically. An occasional aggressor behaves aggressively is it is beneficial. They can often be charming, but then aggressive to peers, teachers and siblings, they behave impulsively, later they regret. They have leadership ambitions, can be physically strong, can be persuasive, manipulative, with other antisocial behaviour (such as shouting) when things are not done as they prefer. They may burst with anger. However, their self-esteem is sufficient. These characteristics are often found in pupils whose self-confidence can be sufficiently high. Such pupils need clear and strict rules and should know the results of their actions. We should also teach them to empathize with others (empathy). A chronic aggressor aggressive behaviour is their personal trait, they are not able to control themselves. Their attitude to violence is positive, they feel uncertain and oppressedF. They are distracting. They refuse to take responsibility for their actions. They have no sympathy with their victims. They feel less appreciated. They are typical aggressors, often abused and neglected at home. Similarly, Rozvadský Gugová and Eisemann (2016) found a correlation between: Rejection (father) and Rejection (mother) subscale $(\mathrm{r}=.655, \mathrm{p}$ $<.001)$. These pupils attack the weaknesses of others, which gives them a sense of fulfilment and power.

The most reliable means of preventing pupils from aggression in schools is to prevent it completely. The most effective prevention should be done by the school management, pedagogical and non-teaching staff together with the pupils' parents (Hanuliaková, Hasajová, \& Porubčanová, 2017). The way to build prevention and remedy must be systematic and rational, because aggression, especially repeated, is by no means a matter only for the aggressor and the victim but it is a serious disease of the whole group (Tamášová \& Barnová, 2011). Students associate positive school climate with a higher motivation to study, experiencing success; personal development; discovery learning which brings them pleasure; increasing prosocial attitudes and behaviour (Hanuliaková \& Barnová, 2015; Andreassen et al, 2016).

Repeated aggression and bullying represent one of the forms of delinquent behaviour. Regarding this, prevention is defined as scientifically motivated, deliberate, purposeful, planned and coordinated action on causes and conditions of criminality with the aim of eliminating and appropriate selection of forms and methods of attenuation to minimize or, if necessary, to limit their negative manifestations while simultaneously promoting anti-criminogenic conditions (Erb, 2000, p. 19). 


\section{Acta Educationis Generalis \\ volume 8, 2018, issue 1}

\section{Methods}

Related to the analysed problem, a research was carried out dealing with the survey of aggression level of majority pupils compared to pupils from socially disadvantaged environment. There were six monitoring procedures of sixty teachers $(53$ females and 7 males). In total, 60 lessons were monitored. The monitoring was carried out personally, based on a monitoring scheme of aggression of pupils from socially disadvantaged environment.

We were interested in differences in the level of aggression of majority pupils compared to pupils from socially disadvantaged environment in the first and fourth grade.

To analyse the significant difference between the respondents in different grades (the first and the fourth), we used Mann-Whitney U-test. The results are described below. The data are also shown in tables revealing the significant difference. To complete the data, supplementary table are shown with the data of Mann-Whitney U-test related to aggression of respondents of the first and fourth grade and the data of Mann-Whitney Utest related to aggression of respondents in compulsory and optional classes.

\section{Research results}

The results describe the significant differences. Based on the monitoring of verbal aggression in the first grade, there were significant differences for "mocking", "ignoring", "verbal assaults, threats", in favour of the respondents from the disadvantaged environment (at the significance level of 0.01).

"Gossiping" as an item in the score sheet did not report a significant difference. Regarding other items, such as "stealing things", "damaging and destructing things", "hiding things", there was also a significant difference in favour of the respondents from the disadvantaged environment in the first grade (the significance level of 0.01). The same difference was found (at the significance level of 0.01) in the first-grade pupils from the disadvantaged environment for the item "forced demeaning behaviour" (Table 1, Table 2).

Table 1

Significance of differences in aggression of pupils from socially disadvantaged environment in $1^{\text {st }}$ year of primary school

\begin{tabular}{|c|c|c|c|}
\hline Questions & $\frac{\frac{N 1-\text { majority }}{\text { pupils. }}}{1^{\text {st }} \text { year }}$ & 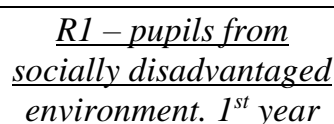 & $\frac{\text { Mann-Whitney } U}{\underline{\text { test }}}$ \\
\hline ot_1a-gossiping & 2.57 & 2.45 & 0.01 \\
\hline ot_1b-mocking & 1.77 & 4.11 & $4.66 * *$ \\
\hline ot_1c - ignoring & 0.57 & 1.34 & $2.61 * *$ \\
\hline $\begin{array}{l}\text { ot_1d - verbal assaults, } \\
\text { threats }\end{array}$ & 3.05 & 6.77 & $3.70 * *$ \\
\hline $\begin{array}{l}\text { ot_1e - threatening with } \\
\text { a gun }\end{array}$ & 0 & 0 & 0 \\
\hline ot_2a - stealing things & 0.31 & 1.68 & $4.63 * *$ \\
\hline $\begin{array}{l}\text { ot_2b - damaging and } \\
\text { destructing things }\end{array}$ & 0.42 & 2 & $4.83 * *$ \\
\hline ot_2c-hiding things & 0.11 & 0.54 & $2.17 * *$ \\
\hline
\end{tabular}




\section{Acta Educationis Generalis \\ volume 8,2018 , issue 1}

\begin{tabular}{llll}
\hline $\begin{array}{l}\text { ot_3a-forced } \\
\text { demeaning behaviour }\end{array}$ & 0.11 & 0.74 & $2.83 * *$ \\
$\begin{array}{l}\text { ot_3b-forced } \\
\text { demeaning eating }\end{array}$ & 0 & 0 & 0 \\
$\begin{array}{l}\text { ot_3c -forced services } \\
\text { ot_3d - nonsense }\end{array}$ & 0 & 0 & 0 \\
$\begin{array}{l}\text { commands and } \\
\text { restrictions }\end{array}$ & 0.25 & 0.65 & 0.50 \\
\hline
\end{tabular}

Table 2

Mann-Whitney $U$ test of aggression in the respondents of the $1^{\text {st }}$ year of primary school

\begin{tabular}{|c|c|c|c|c|c|c|c|c|c|c|}
\hline \multirow[b]{2}{*}{ Variable } & \multicolumn{10}{|c|}{$\begin{array}{l}\text { Mann-Whitney U test (data_agresia.sta) } \\
\text { According to variables. year } \\
\text { Marked tests are significant at level } p<, 05000\end{array}$} \\
\hline & $\mathrm{N} 1$ & R1 & $\mathrm{U}$ & Z & p-value & Z & p-value & \begin{tabular}{|c|}
$\begin{array}{c}\text { N platn. } \\
\text { N1 }\end{array}$ \\
\end{tabular} & \begin{tabular}{|c|}
$\begin{array}{c}\text { N platn. } \\
\text { R1 }\end{array}$ \\
\end{tabular} & $\begin{array}{l}2 * 1 \\
\text { exact } p\end{array}$ \\
\hline ot_1a & 1240,500 & 1244,500 & 610,5000 & $-0,01762$ & 0,985943 & $-0,01785$ & 0,985757 & 35 & 35 & 0,981379 \\
\hline ot_1b & 845,500 & 1639,500 & 215,5000 & $-4,65733$ & 0,000003 & $-4,71544$ & 0,000002 & 35 & 35 & 0,000001 \\
\hline ot_1c & 1019,500 & 1465,500 & 389,5000 & $-2,61351$ & 0,008962 & $-2,80310$ & 0,005062 & 35 & 35 & 0,008230 \\
\hline ot_1d & 926,500 & 1558,500 & 296,5000 & $-3,70589$ & 0,000211 & $-3,72395$ & 0,000196 & 35 & 35 & 0,000139 \\
\hline ot_1e & 1242,500 & 1242,500 & 612,5000 & 0,00587 & 0,995314 & & & 35 & 35 & \\
\hline ot_2a & 848,000 & 1637,000 & 218,0000 & $-4,62796$ & 0,000004 & $-4,95795$ & 0,000001 & 35 & 35 & 0,000001 \\
\hline ot_2b & 830,500 & 1654,500 & 200,5000 & $-4,83352$ & 0,000001 & $-5,08089$ & 0,000000 & 35 & 35 & 0,000000 \\
\hline ot $2 \mathrm{c}$ & 1057,500 & 1427,500 & 427,5000 & $-2,16715$ & 0,030224 & $-2,83728$ & 0,004550 & 35 & 35 & 0,029152 \\
\hline ot_3a & 1001,000 & 1484,000 & 371,0000 & $-2,83081$ & 0,004643 & $-3,51458$ & 0,000441 & 35 & 35 & 0,004189 \\
\hline ot_3b & 1242,500 & 1242,500 & 612,5000 & 0,00587 & 0,995314 & & & 35 & 35 & \\
\hline ot_3c & 1242,500 & 1242,500 & 612,5000 & 0,00587 & 0,995314 & & & 35 & 35 & \\
\hline ot $3 d$ & 1199,500 & 1285,500 & 569,5000 & $-0,49921$ & 0,617633 & $-0,66489$ & 0,506124 & 35 & 35 & 0,615608 \\
\hline
\end{tabular}

Notes:

$* *$ - significant at the level of $\mathrm{p}<0.01000 ; *$ - significant at the level of $\mathrm{p}<0.05000 ; \mathrm{N} 1$ - majority pupils, $1^{\text {st }}$ year;

R1 - pupils from socially disadvantaged environment. $1^{\text {st }}$ year; ot_1a - gossiping; ot_1b - mocking; ot_1c ignoring; ot_1d - verbal assaults, threats; ot_1e - threatening with a gun; ot_2a - stealing things; ot_2b damaging and destructing things; ot_2c - hiding things; ot_3a - forced demeaning behaviour; ot_3b - forced demeaning eating; ot_3c - forced services; ot_3d - nonsense commands and restrictions

Based on the monitoring of the $1^{\text {st }}$ year, there was a significant difference in "physical harm" and "degrading acts and touches" (at the level of significance of 0.01) in favour of the respondents from the disadvantaged environment. The same group of respondents reported a significant difference in monitoring the aggressors in the class. The pupilsaggressors from the $1^{\text {st }}$ class came from the disadvantaged environment (Table 3 , Table 4).

The survey also monitored the attitude of the pupils to aggression. The first-year pupils most commonly "entertain by it", they "admire the aggressors" and they "are the actors". These items reported a significant difference in favour of the respondents from the disadvantaged environment (at the significance level of 0.01). 


\section{Acta Educationis Generalis \\ volume 8,2018 , issue 1}

Table 3

Significant differences between the measured values concerning predominant aggression and attitudes towards it in pupils from socially disadvantaged environment in the first year of primary school

\begin{tabular}{|c|c|c|c|}
\hline Questions & $\frac{\frac{N 1-\text { majority }}{\text { pupils. }}}{\underline{1^{\text {st } y e a r}}}$ & $\frac{\frac{R l-\text { pupils from socially }}{\text { disadvantaged environment } .}}{\underline{1^{\text {st }} \text { year }}}$ & $\frac{\frac{\text { Mann- }}{\text { Whitney } U}}{\underline{\text { test }}}$ \\
\hline ot_4a-physical harm & 0.88 & 3.08 & $5 . \overline{05 * *}$ \\
\hline $\begin{array}{l}\text { ot_4b-simulated } \\
\text { violence }\end{array}$ & 1.88 & 2.66 & 1.93 \\
\hline $\begin{array}{l}\text { ot_4c degrading acts and } \\
\text { touches }\end{array}$ & 0.29 & 0.97 & $2.83 * *$ \\
\hline ot_5a-a boy & 1.74 & 2.74 & $2.55 * *$ \\
\hline ot_5b-a girl & 0.31 & 0.86 & 1.90 \\
\hline ot_5c - a group of boys & 1.94 & 2.74 & $2.41 * *$ \\
\hline ot_5d - a group of girls & 0.29 & 0.51 & 0.81 \\
\hline ot_5e - a teacher & 0 & 0 & 0 \\
\hline $\begin{array}{l}\text { ot_6a }- \text { they refuse } \\
\text { aggression }\end{array}$ & 0.71 & 0.69 & 0.13 \\
\hline $\begin{array}{l}\text { ot_6b-they accept } \\
\text { aggression }\end{array}$ & 0.34 & 0.37 & 0.74 \\
\hline $\begin{array}{l}\text { ot_6c - they pay no } \\
\text { attention }\end{array}$ & 0.26 & 0.29 & 0.34 \\
\hline $\begin{array}{l}\text { ot_ } 6 \mathrm{~d}-\text { they watch it as } \\
\text { they are curious }\end{array}$ & 2.37 & 2.80 & 1.15 \\
\hline $\begin{array}{l}\text { ot_6e - they attach little } \\
\text { importance to it }\end{array}$ & 0.34 & 0.57 & 1.14 \\
\hline $\begin{array}{l}\text { ot_6f - they entertain by } \\
\text { it }\end{array}$ & 1.86 & 2.86 & $2.64 * *$ \\
\hline $\begin{array}{l}\text { ot_6g - they support } \\
\text { aggression }\end{array}$ & 0.77 & 1.25 & 1.86 \\
\hline $\begin{array}{l}\text { ot_6h - they admire the } \\
\text { aggressors }\end{array}$ & 0.40 & 1.37 & $3.50 * *$ \\
\hline $\begin{array}{l}\text { ot_6i }- \text { they are the } \\
\text { actors }\end{array}$ & 1.40 & 2.48 & $3.33 * *$ \\
\hline $\begin{array}{l}\text { ot_6j-another option } \\
\text { (which?) }\end{array}$ & 0 & 0 & 0 \\
\hline
\end{tabular}




\section{Acta Educationis Generalis \\ volume 8,2018 , issue 1}

Table 4

Mann-Whitney $U$ test of aggression in the respondents of the $1^{\text {st }}$ year of primary school

\begin{tabular}{|c|c|c|c|c|c|c|c|c|c|c|}
\hline \multirow[b]{2}{*}{ Variable } & \multicolumn{10}{|c|}{$\begin{array}{l}\text { Mann-Whitney U test (data_agresia.sta) } \\
\text { According to variables. year } \\
\text { Marked tests are significant at level } p<, 05000\end{array}$} \\
\hline & N1 & R1 & $\mathrm{U}$ & Z & p-value & 2 & p-value & $\begin{array}{c}\text { N platn. } \\
\text { N1 }\end{array}$ & $\begin{array}{c}\text { N platn. } \\
\text { R1 }\end{array}$ & $\begin{array}{l}2 * 1 \\
\text { exact } p\end{array}$ \\
\hline ot_4a & 812,000 & 1673,000 & 182,0000 & $-5,05082$ & 0,000000 & $-5,16821$ & 0,000000 & 35 & 35 & 0,000000 \\
\hline ot_4b & 1077,500 & 1407,500 & 447,5000 & $-1,93223$ & 0,053332 & $-1,97394$ & 0,048389 & 35 & 35 & 0,052214 \\
\hline ot_4c & 1001,000 & 1484,000 & 371,0000 & $-2,83081$ & 0,004643 & $-3,18648$ & 0,001440 & 35 & 35 & 0,004189 \\
\hline ot_5a & 1025,000 & 1460,000 & 395,0000 & $-2,54890$ & 0,010807 & $-2,60046$ & 0,009310 & 35 & 35 & 0,010193 \\
\hline ot_5b & 1080,500 & 1404,500 & 450,5000 & $-1,89699$ & 0,057830 & $-2,34693$ & 0,018929 & 35 & 35 & 0,056716 \\
\hline ot_5c & 1036,500 & 1448,500 & 406,5000 & $-2,41382$ & 0,015787 & $-2,47578$ & 0,013295 & 35 & 35 & 0,014878 \\
\hline ot_5d & 1173,000 & 1312,000 & 543,0000 & $-0,81048$ & 0,417665 & $-1,00766$ & 0,313617 & 35 & 35 & 0,420035 \\
\hline ot_5e & 1242,500 & 1242,500 & 612,5000 & 0,00587 & 0,995314 & & & 35 & 35 & \\
\hline ot_6a & 1254,500 & 1230,500 & 600,5000 & 0,13508 & 0,892549 & 0,14965 & 0,881038 & 35 & 35 & 0,888623 \\
\hline ot_6b & 1179,000 & 1306,000 & 549,0000 & $-0,74000$ & 0,459298 & $-0,91736$ & 0,358952 & 35 & 35 & 0,461688 \\
\hline ot_6c & 1272,000 & 1213,000 & 583,0000 & 0,34064 & 0,733377 & 0,48953 & 0,624464 & 35 & 35 & 0,734975 \\
\hline ot_6d & 1144,500 & 1340,500 & 514,5000 & $-1,14524$ & 0,252109 & $-1,17552$ & 0,239788 & 35 & 35 & 0,251418 \\
\hline ot_6e & 1145,000 & 1340,000 & 515,0000 & $-1,13937$ & 0,254549 & $-1,36279$ & 0,172950 & 35 & 35 & 0,256316 \\
\hline ot_6f & 1017,500 & 1467,500 & 387,5000 & $-2,63700$ & 0,008365 & $-2,67817$ & 0,007403 & 35 & 35 & 0,007654 \\
\hline ot_6g & 1084,000 & 1401,000 & 454,0000 & $-1,85588$ & 0,063471 & $-1,95693$ & 0,050357 & 35 & 35 & 0,063210 \\
\hline ot_6h & 944,000 & 1541,000 & 314,0000 & $-3,50034$ & 0,000465 & $-3,83194$ & 0,000127 & 35 & 35 & 0,000346 \\
\hline ot_6i & 958,500 & 1526,500 & 328,5000 & $-3,33002$ & 0,000869 & $-3,50979$ & 0,000449 & 35 & 35 & 0,000673 \\
\hline ot_6j & 1242,500 & 1242,500 & 612,5000 & 0,00587 & 0,995314 & & & 35 & 35 & \\
\hline
\end{tabular}

Notes:

** - significant at the level of $\mathrm{p}<0.01000 ; *$ - significant at the level of $\mathrm{p}<0.05000 ; \mathrm{N} 1$ - majority pupils, $1^{\text {st }}$ year; R1 - pupils from socially disadvantaged environment. $1^{\text {st }}$ year; ot_4a - physical harm; ot_4b - simulated violence; ot_4c - degrading acts and touches; ot_5a - a boy; ot_5b - a girl; ot_5c - a group of boys; ot_5d - a group of girls; ot_5e - a teacher; ot_6a - they refuse aggression; ot_6b - they accept aggression; ot_6c - they pay no attention; ot_6d - they watch it as they are curious; ot_6e - they attach little importance to it; ot_6f they entertain by it; ot_6g - they support aggression; ot_6h - they admire the aggressors; ot_6i - they are the actors; ot_6j - another option (which?)

The monitoring of the $4^{\text {th }}$ year revealed a significant difference in "physical harm" and "degrading acts and touches" (at the level of significance of 0.01) in favour of the respondents from the disadvantaged environment (Table 5, Table 6).

In the $4^{\text {th }}$ year, the aggressors were usually the girls from the disadvantaged environment and a group of boys from the disadvantaged environment. These differences are shown in Table 6. The respondents "watch the aggression as they are curious", they "entertain by it" and they "are the actors". Those items reported the significant differences in favour of the four-year respondents from the disadvantaged environment. 


\section{Acta Educationis Generalis \\ volume 8,2018 , issue 1}

Table 5

Significant differences between the measured values concerning predominant aggression and attitudes towards it in pupils from socially disadvantaged environment in the fourth year of primary school

\begin{tabular}{|c|c|c|c|}
\hline Questions & $\frac{\text { N1-majority }}{\text { pupils. } 4^{\text {th }} \text { year }}$ & $\begin{array}{c}\frac{R 1-\text { pupils from socially }}{\text { disadvantaged }} \\
\text { environment } 4^{\text {th }} \text { year }\end{array}$ & $\frac{\frac{\text { Mann- }}{\text { Whitney } U}}{\underline{\text { test }}}$ \\
\hline ot_4a-physical harm & 0.64 & 2.56 & $\overline{4.05} * *$ \\
\hline $\begin{array}{l}\text { ot_ } 4 \mathrm{~b}-\text { simulated } \\
\text { violence }\end{array}$ & 1.72 & 2.68 & 1.54 \\
\hline $\begin{array}{l}\text { ot_4c degrading acts and } \\
\text { touches }\end{array}$ & 0.24 & 1.36 & $4.09 * *$ \\
\hline ot_5a - a boy & 1.84 & 2.44 & 1.90 \\
\hline ot_5b-a girl & 0.20 & 2.20 & $5.02 * *$ \\
\hline ot_5c - a group of boys & 1.36 & 2.80 & $2.97 * *$ \\
\hline ot_5d - a group of girls & 0.60 & 0.80 & 0.48 \\
\hline ot_5e - a teacher & 0 & 0 & 0 \\
\hline $\begin{array}{l}\text { ot_6a - they refuse } \\
\text { aggression }\end{array}$ & 0.60 & 0.24 & 1.53 \\
\hline $\begin{array}{l}\text { ot_6b - they accept } \\
\text { aggression }\end{array}$ & 0.04 & 0.24 & 1.20 \\
\hline $\begin{array}{l}\text { ot_6c }- \text { they pay no } \\
\text { attention }\end{array}$ & 0.32 & 0.28 & 0.05 \\
\hline $\begin{array}{l}\text { ot_6d - they watch it as } \\
\text { they are curious }\end{array}$ & 3.12 & 1.44 & $3.54 * *$ \\
\hline $\begin{array}{l}\text { ot_6e }- \text { they attach little } \\
\text { importance to it }\end{array}$ & 0.72 & 0.56 & 0.45 \\
\hline $\begin{array}{l}\text { ot_6f - they entertain by } \\
\text { it }\end{array}$ & 1.08 & 2.36 & $3.02 * *$ \\
\hline $\begin{array}{l}\text { ot_6g - they support } \\
\text { aggression }\end{array}$ & 0.92 & 1.08 & 0 \\
\hline $\begin{array}{l}\text { ot_6h - they admire the } \\
\text { aggressors }\end{array}$ & 1.08 & 0.88 & 0.69 \\
\hline $\begin{array}{l}\text { ot_6i - they are the } \\
\text { actors }\end{array}$ & 1.20 & 2.64 & $3.44 * *$ \\
\hline $\begin{array}{l}\text { ot_6j-another option } \\
\text { (which?) }\end{array}$ & 0 & 0 & 0 \\
\hline
\end{tabular}




\section{Acta Educationis Generalis \\ volume 8,2018 , issue 1}

Table 6

Mann-Whitney $U$ test of aggression in the respondents of the 4th year of primary school

\begin{tabular}{|c|c|c|c|c|c|c|c|c|c|c|}
\hline \multirow[b]{2}{*}{ Variable } & \multicolumn{10}{|c|}{$\begin{array}{l}\text { Mann-Whitney U test (data_agresia.sta) } \\
\text { According to variables. year } \\
\text { Marked tests are significant at level } p<, 05000\end{array}$} \\
\hline & $\mathrm{N} 4$ & R4 & $\mathrm{U}$ & $\mathrm{Z}$ & p-value & $Z$ & p-value & $\begin{array}{c}\text { N platn. } \\
\text { N4 }\end{array}$ & $\begin{array}{c}\text { N platn. } \\
\text { R4 } \\
\end{array}$ & $\begin{array}{l}2 * 1 \\
\text { exact } p\end{array}$ \\
\hline ot_4a & 428,0000 & 847,0000 & 103,0000 & $-4,05520$ & 0,000050 & $-4,19900$ & 0,000027 & 25 & 25 & 0,000020 \\
\hline ot_4b & 557,5000 & 717,5000 & 232,5000 & $-1,54253$ & 0,122947 & $-1,57135$ & 0,116102 & 25 & 25 & 0,121291 \\
\hline ot_ $4 \mathrm{c}$ & 426,0000 & 849,0000 & 101,0000 & $-4,09400$ & 0,000042 & $-4,44827$ & 0,000009 & 25 & 25 & 0,000016 \\
\hline ot_5a & 539,0000 & 736,0000 & 214,0000 & $-1,90148$ & 0,057240 & $-1,98872$ & 0,046733 & 25 & 25 & 0,056757 \\
\hline ot_5b & 378,0000 & 897,0000 & 53,0000 & $-5,02534$ & 0,000001 & $-5,39708$ & 0,000000 & 25 & 25 & 0,000000 \\
\hline ot $5 \mathrm{c}$ & 484,0000 & 791,0000 & 159,0000 & $-2,96864$ & 0,002991 & $-3,04121$ & 0,002357 & 25 & 25 & 0,002471 \\
\hline ot_5d & 612,0000 & 663,0000 & 287,0000 & $-0,48507$ & 0,627626 & $-0,53311$ & 0,593958 & 25 & 25 & 0,630517 \\
\hline ot_5e & 637,5000 & 637,5000 & 312,5000 & 0,00970 & 0,992260 & & & 25 & 25 & \\
\hline ot_6a & 717,0000 & 558,0000 & 233,0000 & 1,53283 & 0,125320 & 1,86682 & 0,061928 & 25 & 25 & 0,126084 \\
\hline ot_6b & 575,0000 & 700,0000 & 250,0000 & $-1,20298$ & 0,228986 & $-2,00123$ & 0,045369 & 25 & 25 & 0,231218 \\
\hline ot_6c & 640,5000 & 634,5000 & 309,5000 & 0,04851 & 0,961312 & 0,06510 & 0,948094 & 25 & 25 & 0,954003 \\
\hline ot_6d & 820,5000 & 454,5000 & 129,5000 & 3,54102 & 0,000399 & 3,60908 & 0,000307 & 25 & 25 & 0,000240 \\
\hline ot $6 \mathrm{e}$ & 661,0000 & 614,0000 & 289,0000 & 0,44627 & 0,655406 & 0,49522 & 0,620443 & 25 & 25 & 0,658147 \\
\hline ot_6f & 481,5000 & 793,5000 & 156,5000 & $-3,01714$ & 0,002552 & $-3,10013$ & 0,001935 & 25 & 25 & 0,002001 \\
\hline ot $6 \mathrm{~g}$ & 632,5000 & 642,5000 & 307,5000 & $-0,08731$ & 0,930423 & $-0,09563$ & 0,923814 & 25 & 25 & 0,923413 \\
\hline ot_6h & 674,0000 & 601,0000 & 276,0000 & 0,69850 & 0,484863 & 0,74192 & 0,458137 & 25 & 25 & 0,488209 \\
\hline ot_6i & 459,5000 & 815,5000 & 134,5000 & $-3,44401$ & 0,000573 & $-3,59730$ & 0,000322 & 25 & 25 & 0,000367 \\
\hline ot 6 j & 637,5000 & 637,5000 & 312,5000 & 0,00970 & 0,992260 & & & 25 & 25 & \\
\hline
\end{tabular}

Notes:

** - significant at the level of $\mathrm{p}<0.01000 ; *$ - significant at the level of $\mathrm{p}<0.05000 ; \mathrm{N} 4$ - majority pupils, $4^{\text {th }}$ year; R4 - pupils from socially disadvantaged environment. $4^{\text {th }}$ year; ot_4a - physical harm; ot_4b - simulated violence; Ot_4c degrading acts and touches; ot_5a - a boy; ot_5b - a girl; ot_5c - a group of boys; ot_5d - a group of girls; ot_5e - a teacher; ot_6a - they refuse aggression; ot_6b - they accept aggression; ot_6c - they pay no attention; ot_6d - they watch it as they are curious; ot_6e - they attach little importance to it; ot_6f they entertain by it; ot_6g - they support aggression; ot_6h - they admire the aggressors; ot_6i - they are the actors; ot_6j-another option (which?)

\section{Discussion}

In the current society, one of the trends is to have rights. It means that children have their rights, too. It is important to realize that rights bring responsibilities Children are not an exception, they should be aware of that - especially about the responsibility for the violation of other children's rights. Some children lack empathy, they have too much freedom and noone teaches them how to behave properly. As a result, aggression and bullying are still occurring in schools.

What should be done in order to protect our children in schools and school facilities from bullying and aggression? We believe that targeted activities of prevention would be a solid basis for decreasing or even eliminating the occurance of bullying in schools. Setting and following clear rules is one of the steps leading towards the elimination of aggression. It is necessary to fight against the lack of knowledge, downplaying, denial, silence and indifference, which are still present in our schools. Special attention should be paid to the aggressors, to the causes and reasons behind their behaviour. It is necessary to keep providing appropriate and sufficient information to all the pedagogues and school managing authorities. There is also a need for prevention targeted not only on pupils but also on teachers and parents. It is strongly recommended to develop friendly, open and safe relationships among all the members of school community, i.e. to create a 


\section{Acta Educationis Generalis \\ volume 8, 2018, issue 1}

favourable social climate which we consider to be the basic form of the prevention of aggressive behaviour and bullying in schools.

\section{Conclusion}

Effective prevention of any aggression is linked to the requirement that parents accept and love children as the children are, regardless their appearance, intellect, ability. The parents should communicate with their child, talk to them about their experiences at school and friends, about their needs, values; giving the child attention, looking at their problems, worries and joy. They should form a healthy self-confidence of a child, in the form of commendations and awards, but also by good critic. They need to identify the child's borders, the limits of what is allowed and what is not allowed; setting rules that provide the child with certainty, as a reference point that should be kept. The children also should be able to deal with their emotions (such as anger, hatred, anger, etc.), and realized that the manifestations of anger and aggression are the result of their own failure and can become a model of conflict resolution (Kominarec, 2009).

What is therefore necessary to do to protect the children at schools and school facilities from bullying and violence? We believe that proper prevention should be the appropriate first step to prevent, or even reduce, bullying in schools. Establishing rules and keeping them is a further precondition for preventing aggression. It is important to break ignorance, attaching low importance, denial, silence and indifference that occur in our schools. Attention should also be paid to the aggressor and the reason of the behaviour. It is vitally important to keep the educators and school management well informed. There is also a need for constant preventive action not only for pupils, but also for teachers and parents. It is very appropriate to build friendly, open and secure relationships among all the members of the school, to build a favourable social climate that we think is an important part of prevention against aggression and bullying in schools.

Furthermore, in order to deal with aggression and bullying, there is a need for people who are courageous, sensitive, willing to deal with this issue, but also for openness to this problem and the implementation of effective interventions. We believe that aggression and bullying now belong to serious social problems that occur in many forms and act destructively to the personality of a person.

\section{Acknowledgements}

The authors gratefully acknowledge the contribution of the KEGA Grant Agency of the Slovak Republic under the KEGA Project 005DTI-4/2018 "Support stategies of students adherence to the rules in educational environment".

\section{References}

Andreassen, C. S., Billieux, J., Griffiths, M. D., Kuss, D. J., Demetrovics, Z., Mazzoni, E., \& Pallesen, S. (2016). The relationship between addictive use of social media and video games and symptoms of psychiatric disorders: A large-scale crosssectional study. Psychology of Addictive Behaviors, 30(2), 252-262. doi: 10.1037/adb0000160

Čermák, I. (1999). Lidská agrese a jeji souvislosti. Žd'ár nad Sázavou: Fakta, 1999.

Dupkalová, M., \& Krajčová, N. (2015). Interakčný štýl učitel’a a sociálna klíma v školskej triede. Prešov: Expres Print Prešov. 


\section{Acta Educationis Generalis \\ volume 8,2018 , issue 1}

Erb, H. (2000). Násilí ve škole a jak mu čelit. Praha: Amulet.

Hanuliaková, J., \& Barnová, S. (2015). Positive School Climate (A Theoretical Empirical Conspectus). Acta Technologica Dubnicae, 5(1), 68-73. doi: 10.1515/atd-2015-0035

Hanuliaková, J., Hasajová, L., \& Porubčanová, D. (2017). Stress of students and socialpathological phenomena. Acta Technologica Dubnicae, 6(3), 112-121 doi: 10.1515/atd-2016-0023

Határ, C. (2004). Terminologické poznatky k agresii a agresívnemu správaniu detí. Mládež a spoločnost', 10(1), 13-21.

Koláŕ, M. (2001). Bolest šikanování. Praha: Portál.

Kominarec, I. (2009). Pedagogika ogólna: podstawowe zagadnenia. Czestochowa: Wydawnictwo Wyzszej szkoly lingwistycznej.

Kyriacou, C. (2001). Teacher stress: Directions for future research. Educational Review, 53(1), 27-35. doi:10.1080/00131910120033628

Rozvadský Gugová, G., \& Eisemann, M. (2016). Psychometric Properties of the Slovak Version of sEMBU on General Adult Sample. Acta Technologica Dubnicae, 6(3), 32-43 doi: 10151/atd-2016-0018

Spurný, J. (1996). Psychologie násili. Praha: EUROUNION.

Tamašová, V., \& Barnová, S. (2011). School climate as the determinant of the relationship between the level of student s resilience and school satisfaction. Acta Technologica Dubnicae, 1(1), 19-37. doi: 10.1515/atd-2015-0037

Verbovská, J. (2001). Šikanovanie v škole. Prešov: Rokus.

Výrost, J., \& Slaměník, I. (2008). Sociální psychologie 2. Praha: Grada Publishing, 2008. ISBN 97-880247-14-228.

Zahatňanská, M. (2015). Žiak s problémami v škole. Prešov: Prešovská univerzita v Prešove FHPV. 